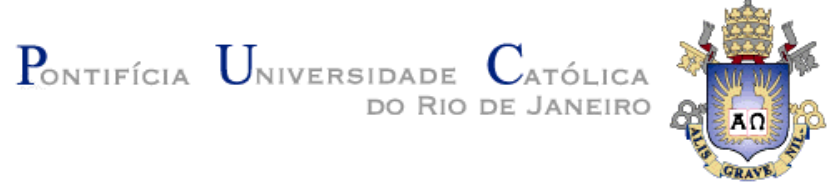

Mariana Ribeiro Marques

Afeto e sensorialidade no pensamento de
B. Espinosa, S. Freud e D. W. Winnicott

Dissertação de Mestrado

Dissertação apresentada como requisito parcial para obtenção do grau de Mestre pelo Programa de Pós-graduação em Psicologia Clínica do Departamento de Psicologia da PUC-Rio.

Orientador: Prof. Carlos Augusto Peixoto Junior

Rio de Janeiro

Março de 2012 
Mariana Ribeiro Marques

\section{Afeto e sensorialidade no pensamento de B. Espinosa, S. Freud e D. W. Winnicott}

Dissertação apresentada como requisito parcial para obtenção do grau de Mestre pelo Programa de Pósgraduação em Psicologia Clínica do Departamento de Psicologia da PUC-Rio. Aprovada pela Comissão Examinadora abaixo assinada

Prof. Carlos Augusto Peixoto Jr. Orientador Departamento de Psicologia - PUC-Rio

Prof. Auterives Maciel Junior Departamento de Psicologia - PUC-Rio

Profa. Cristina Mair Barros Rauter Instituto de Ciências Humanas e Filosofia - UFF

Profa. Denise Berruezo Portinari Coordenadora Setorial de Pós-Graduação

e Pesquisa do Centro de Teologia e Ciências Humanas - PUC-Rio

Rio de Janeiro, 27 de março de 2012. 
Todos os direitos reservados. É proibida a reprodução total ou parcial do trabalho sem a autorização da universidade, da autora e do orientador.

\section{Mariana Ribeiro Marques}

Graduou-se em Psicologia na PUC-Rio em 2009. Atualmente é psicóloga clínica na ONG Casa da Árvore.

Ficha Catalográfica

Marques, Mariana Ribeiro

Afeto e sensorialidade no pensamento de B. Espinosa, S. Freud e D. W. Winnicott / Mariana Ribeiro Marques ; orientador: Carlos Augusto Peixoto Junior. - 2012. $135 \mathrm{f}$; ; $30 \mathrm{~cm}$

Dissertação (mestrado)-Pontifícia Universidade Católica do Rio de Janeiro, Departamento de Psicologia, 2012. Inclui bibliografia

1. Psicologia - Teses. 2. Afeto. 3. Representação. 4. Pulsão. 5. Sensorialidade. 6. Experiência. 7. Psicanálise. 8. Filosofia. I. Peixoto Junior, Carlos Augusto. II. Pontifícia Universidade Católica do Rio de Janeiro. Departamento de Psicologia. III. Título. 


\section{Agradecimentos}

A Carlos Augusto Peixoto, por acompanhar o percurso desta pesquisa desde a graduação, auxiliando na construção de linhas de fuga para o pensamento da psicanálise e na sua interlocução com outros campos do conhecimento.

A Auterives Maciel, pelo diálogo profícuo e apoio afetuoso à realização deste trabalho.

A Maurício Rocha, pelo bom encontro que me proporcionou conhecer o pensamento de Espinosa pela via da alegria.

A Cristina Rauter, pela generosidade e interesse nos temas tratados nesta dissertação.

Ao Juliano, pela troca e apoio afetivo.

Ao Zé Otávio, pelo auxílio na construção de planos de consistência para o meu desejo.

A Fernando, Larissa, Lívia e Bia, companheiros de ideias e práticas, e parceiros queridos durante a escrita deste trabalho.

A Amanda, Gabi, Lia, Rachel e Renata, por existirem e estarem sempre por perto, mesmo que longe.

A Sonia Argollo, pela revisão atenta e cuidadosa do texto original.

Aos professores da PUC-Rio, pelo estímulo à produção de conhecimento.

Aos funcionários da PUC-Rio e do Departamento de Psicologia, cuja dedicação foi essencial para a confecção deste trabalho.

À CAPES e à PUC-Rio, pelos auxílios concedidos. 


\section{Resumo}

Marques, Mariana Ribeiro; Peixoto Junior, Carlos Augusto. Afeto e sensorialidade no pensamento de B. Espinosa, S. Freud e D. W. Winnicott. Rio de Janeiro, 2012. 135p. Dissertação de Mestrado Departamento de Psicologia, Pontifícia Universidade Católica do Rio de Janeiro.

Este trabalho se propõe a realizar uma cartografia dos elementos indicadores de uma teoria dos afetos nas obras de B. Espinosa, S. Freud e D. W. Winnicott no âmbito dos processos de subjetivação que descrevem. As relações entre corpo e mente, afeto e representação, assim como a participação da sensorialidade nos processos de constituição subjetiva são alguns dos temas recorrentes em cada um dos autores tratados. Partimos da filosofia prática de Espinosa, em que os afetos são a mola propulsora para o conhecimento e para a expansão de potência. Em seguida, expomos o pensamento de Freud, que tem como base o estudo do conceito de pulsão e o entendimento do afeto como um representante psíquico desta. Por fim, passamos ao estudo da teoria de Winnicott, na qual a experiência sensível é imprescindível aos processos de desenvolvimento emocional. Percorremos as linhas gerais do pensamento desses autores sobre o tema dos afetos e da sensorialidade com o intuito de pensar uma clínica psicanalítica conectada à experiência sensível. Traçamos algumas interlocuções possíveis, assim como apontamos algumas diferenças entre os autores, considerando os diferentes contextos teóricos do qual fazem parte.

\section{Palavras-Chave}

Afeto; Representação; Pulsão; Sensorialidade; Experiência; Psicanálise; Filosofia. 


\section{Abstract}

Marques, Mariana Ribeiro; Peixoto Junior, Carlos Augusto (Advisor). Affection and sensoriality in the theories of B. Espinosa, S. Freud and D. W. Winnicott. Rio de Janeiro, 2012. 135p. MSc. Dissertation Departamento de Psicologia, Pontifícia Universidade Católica do Rio de Janeiro.

This work intends to conduct a cartography of the indicators of a theory of affects in the works of B. Spinoza, S. Freud and D. W. Winnicott in the subjectivation processes they describe. The relationships between body and mind, affection and representation, as well as the participation of the sensoriality in the processes of subjective constitution are some of the recurring themes in each of the authors treated. We start from the practical philosophy of Spinoza, in which the affections are the driving force for knowledge and for the expansion of power. Then we expose Freud's thinking, which is based on the study of the concept of drive and on the understanding of affect as psychic representative of the drive. Finally, we come to the study of Winnicott's theory, in which sensory experience is essential to the processes of emotional development. We go through the general lines of thought of these authors on the subject of affection and sensoriality with the aim of a psychoanalytic thinking connected to sensorial experience. We draw some possible dialogues, as well as point out some differences between the authors, considering the different theoretical contexts to which they belong.

\section{Keywords}

Affection; Representation; Drive; Sensoriality; Experience; Psychoanalysis; Philosophy. 


\section{Sumário}

Introdução

1. Espinosa e a afetividade humana 13

1.1. A substância e os seus modos: singularidade e subjetivação 17

1.2. A consciência e as relações entre corpo e mente 20

1.3. Afeto e duração 27

1.4. Afeto e conhecimento: ação e paixão 30

1.5. Conatus, mecanismos afetivos e desejo 35

1.6. Afeto, política e experiência 43

2. A concepção freudiana do afeto 47

2.1. As primeiras aparições do afeto no texto de Freud 52

2.2. Os avatares do afeto e da representação no mecanismo do recalque $\quad 57$

2.3. Afeto, angústia e sentimentos inconscientes 59

2.4. Terceira síntese metapsicológica e segunda tópica:

pulsão de morte e modelo estrutural do psiquismo 63

2.5. As teorias freudianas da angústia 68

2.6. Considerações finais acerca do afeto em Freud 73

3. D. W. Winnicott: a experiência sensível nos processos de subjetivação $\quad 80$

3.1. Os processos de desenvolvimento emocional 84

3.1.1. Integração no tempo: self e continuidade no ser 87

3.1.2. Integração no espaço: a trama psicossomática 93

3.2. Área da experiência e transicionalidade 99

3.3. A experiência como condição para o viver criativo 108

3.4. Agressividade primária e amor 115

$\begin{array}{ll}\text { Considerações finais } & 120\end{array}$

$\begin{array}{ll}\text { Bibliografia } & 129\end{array}$ 